\title{
Vasopressin Increases Locomotion through a V1a Receptor in Orexin/Hypocretin Neurons: Implications for Water Homeostasis
}

\author{
Tomomi Tsunematsu, ${ }^{1}$ Li-Ying Fu, ${ }^{2}$ Akihiro Yamanaka, ${ }^{1,2}$ Kanako Ichiki, ${ }^{1}$ Akito Tanoue, ${ }^{3}$ Takeshi Sakurai, ${ }^{1}$ and \\ Anthony N. van den $\mathrm{Pol}^{2}$ \\ ${ }^{1}$ Department of Molecular Pharmacology, Graduate School of Comprehensive Human Sciences, University of Tsukuba, Tsukuba, Ibaraki 305-8575, Japan, \\ ${ }^{2}$ Department of Neurosurgery, Yale School of Medicine, New Haven, Connecticut 06520, and ${ }^{3}$ Department of Pharmacology, National Research Institute for \\ Child Health and Development, Tokyo 157-8535, Japan
}

\begin{abstract}
Water homeostasis is a critical challenge to survival for land mammals. Mice display increased locomotor activity when dehydrated, a behavior that improves the likelihood of locating new sources of water and simultaneously places additional demands on compromised hydration levels. The neurophysiology underlying this well known behavior has not been previously elucidated. We report that the anti-diuretic hormone arginine-vasopressin (AVP) is involved in this response. AVP and oxytocin directly induced depolarization and an inward current in orexin/hypocretin neurons. AVP-induced activation of orexin neurons was inhibited by a V1a receptor (V1aR)selective antagonist and was not observed in V1aR knock-out mice, suggesting an involvement of V1aR. Subsequently activation of phospholipase $\mathrm{C} \beta$ triggers an increase in intracellular calcium by both calcium influx through nonselective cation channels and calcium release from calcium stores in orexin neurons. Intracerebroventricular injection of AVP or water deprivation increased locomotor activity in wild-type mice, but not in transgenic mice lacking orexin neurons. V1aR knock-out mice were less active than wild-type mice. These results suggest that the activation of orexin neurons by AVP or oxytocin has an important role in the regulation of spontaneous locomotor activity in mice. This system appears to play a key role in water deprivation-induced hyperlocomotor activity, a response to dehydration that increases the chance of locating water in nature.
\end{abstract}

Key words: orexin; hypocretin; patch clamp; vasopressin; V1a receptor; water deprivation

\section{Introduction}

Arginine-vasopressin (AVP) and oxytocin are closely related peptides. The physiological effect of AVP and oxytocin is mediated through V1a, V1b, V2, and oxytocin receptors. V1a, V1b, and oxytocin receptors are coupled with the $\mathrm{G}_{\mathrm{q}}$ subclass of G-protein and increase phosphatidylinositol hydrolysis to mobilize intracellular calcium (Birnbaumer, 2000). The V2 receptor is coupled to $G_{s}$. AVP and oxytocin are implicated in a variety of functions, including regulation of fluid homeostasis, emotion, social recognition, and reproduction. AVP is well known as an anti-diuretic hormone in peripheral tissue. AVP is released during dehydration. It increases water reabsorption in the kidney. In

Received Aug. 1, 2007; revised 0ct. 9, 2007; accepted 0ct. 30, 2007.

This work was supported by the Japan Society for Promotion of Science postdoctoral Fellowship for research abroad (A.Y.), Grant-in-Aid for Scientific Research on Priority Areas (Integrative brain research) from the Ministry of Education, Culture, Sports, Science, and Technology of Japan (A.Y.), Astellas Foundation for Research on Medicinal Resources, and United States National Institutes of Health Grant NS41454. We thank J. N. Davis and C. Jones for proofreading and Dr. T. Aoyagi, Dr. N. Tsujino, and Y. Muraki for technical assistance.

Before Feb. 1, 2008, correspondence should be addressed to Dr. Akihiro Yamanaka, Department of Molecular Pharmacology, Graduate School of Comprehensive Human Sciences, University of Tsukuba, Tsukuba, Ibaraki 3058575, Japan, E-mail: yamank@md.tsukuba.ac.jp; after Feb. 1, 2008, correspondence should be addressed to Dr. Akihiro Yamanaka, Section of Cell Signaling, Okazaki Institute for Integrative Bioscience, National Institutes of Natural Sciences, 5-1 Higasiyama Myodaiji, Okazaki 444-8787, Japan, E-mail: yamank@dg8.s0-net.ne.jp.

DOI:10.1523/JNEUROSCI.3490-07.2008

Copyright $\odot 2008$ Society for Neuroscience $\quad$ 0270-6474/08/280228-11\$15.00/0 contrast, the physiological importance of AVP and oxytocin release in the CNS is not yet fully understood. Recent studies using knock-out mice have begun to reveal the physiological role of AVP and oxytocin in the CNS. V1a receptor knock-out $\left(V 1 a R^{-1-}\right)$ mice showed abnormalities in spatial memory (Egashira et al., 2004), social interaction and anxiety (Bielsky et al., 2005; Egashira et al., 2007), and metabolism (Hiroyama et al., 2007). Oxytocin knock-out mice revealed that oxytocin plays an important role in social cognition and social, sexual, and maternal behavior (Winslow and Insel, 2002).

Orexin A and orexin B (also called hypocretin-1 and hypocretin-2) are a pair of neuropeptides expressed in a specific population of neurons in the lateral hypothalamic area (de Lecea et al., 1998; Sakurai et al., 1998). Orexin-producing neurons (orexin neurons) are implicated in the regulation of sleep/wakefulness as well as feeding and drinking behavior, and are in synaptic contact with CNS loci that regulate sleep, wakefulness, arousal, and energy homeostasis. Orexin neurons densely project to the monoaminergic and cholinergic nuclei in the hypothalamus/brainstem and activate these neurons (Horvath et al., 1999; Brown et al., 2001; Eggermann et al., 2001; Yamanaka et al., 2002). Orexin neurons receive abundant inputs from the limbic system, the raphe nucleus, and the basal forebrain (Sakurai et al., 2005; Yoshida et al., 2006). Intracellular calcium in orexin neu- 
rons is altered by a number of neuroactive substances, including cholecystokinin, neurotensin, AVP, oxytocin, neuropeptide Y (NPY), adenosine, serotonin, and noradrenaline (Fu et al., 2004; Tsujino et al., 2005; Yamanaka et al., 2006; Liu and Gao, 2007).

Here we studied the mechanism and the physiological importance of AVP- and oxytocin-induced activation of orexin neurons using a number of transgenic mice, including orexin/EGFP (Yamanaka et al., 2003a,b), orexin/ataxin-3 (Hara et al., 2001), and orexin/YC2.1 mice (Tsujino et al., 2005). Slice patch-clamp recording and digital imaging of orexin neurons showed that both oxytocin and AVP directly excited orexin neurons through the $\mathrm{V} 1 \mathrm{aR}$, by a mechanism involving activation of a nonselective cation channel. This was confirmed by using V1aR ${ }^{-/-}$mice. Behavioral analysis of locomotor activity showed the importance of AVP activation of orexin neurons in the dehydration-induced increase in activity.

\section{Materials and Methods}

Animal usage. All experimental procedures involving animals were approved by the University of Tsukuba and Yale University Animal Care and Use Committees and were in accordance with National Institutes of Health guidelines. All efforts were made to minimize animal suffering or discomfort and to reduce the number of animals used.

Animals. Orexin/YC2.1 mice (Tsujino et al., 2005; Yamanaka et al., 2006) were used for calcium imaging of orexin neurons. Orexin/EGFP mice (Yamanaka et al., 2003a,b) were used for whole-cell recordings. The $V 1 a R^{-1-}$ mice (Egashira et al., 2004) were maintained on a mixed genetic background (129sv:C57Black/6J = 1:1). V1aR ${ }^{-1-}$ mice were crossed with orexin/EGFP mice to obtain $V 1 a R^{-/-}$; orexin/EGFP mice. Males and females of $V 1 a R^{+/-}$; orexin/EGFP mice were then crossed to generate $V 1 a R^{-1-}$; orexin/EGFP mice, in which VlaR is not expressed, and EGFP is specifically expressed in the orexin neurons. The littermate mice, $V 1 a R^{+/+}$; orexin/EGFP mice and $V 1 a R^{+/-}$; orexin/EGFP mice, were used for control experiments. Orexin/ataxin-3 mice, in which orexin neurons are specifically ablated, were used for locomotor analysis (Hara et al., 2001).

Brain slice preparation. Orexin/YC2.1 mice (3-8 weeks old), orexin/ EGFP mice (2-3 weeks old), and V1aR ${ }^{-/-}$; orexin/EGFP mice were anesthetized with fluothane (Takeda, Osaka, Japan) or with ketamine and xylazine. The mice were decapitated under deep anesthesia. Brains were isolated in ice-cold cutting solution consisting of the following (in $\mathrm{mM}$ ): 280 sucrose, $2 \mathrm{KCl}, 10 \mathrm{HEPES}, 0.5 \mathrm{CaCl}_{2}, 10 \mathrm{MgCl}_{2}, 10$ glucose, $\mathrm{pH} 7.4$, bubbled with $100 \% \mathrm{O}_{2}$. Brains were cut coronally into $300 \mu \mathrm{m}$ slices with a microtome (VTA-1000S, Leica, Wetzlar, Germany). Slices containing the lateral hypothalamic area were transferred for at least $1 \mathrm{~h}$ to an incubation chamber filled with physiological solution containing the following (in mM): $135 \mathrm{NaCl}, 5 \mathrm{KCl}, 1 \mathrm{CaCl}_{2}, 1 \mathrm{MgCl}_{2}, 10$ HEPES, 10 glucose, pH 7.4 with $\mathrm{NaOH}$.

Calcium imaging of orexin neurons. Orexin/YC2.1 mice were used for calcium imaging. The slices were transferred to a recording chamber (RC-27L, Warner Instrument, Hamden, CT) at a controlled temperature of $34^{\circ} \mathrm{C}$ on a fluorescence microscope stage (BX51WI, Olympus, Tokyo, Japan). Optical recordings were performed on a fluorescence microscope equipped with a cooled charge-coupled device (CCD) camera (Cascade 650, Roper Scientific, Tucson, AZ) controlled by MetaFluor 5.0.7 software (Universal Imaging, West Chester, PA). YC2.1 was excited through a 440DF20 filter, and its fluorescent image was subjected to dual emission ratio imaging through two emission filters (480DF30 for ECFP and 535DF26 for EYFP) controlled by a filter changer (Lambda 10-2, Sutter Instruments, Novato, CA). Images were captured at a rate of $1 \mathrm{~Hz}(300-$ $500 \mathrm{~ms}$ exposure time) with $2 \times 2$ binning through a $20 \times$ UMPlanFI water-immersion objective (Olympus).

Electrophysiological recordings. Orexin/EGFP mice were used for whole-cell recordings. The slices were transferred to a recording chamber (RC-27L, Warner Instrument) at a controlled temperature of $34^{\circ} \mathrm{C}$ on a fluorescence microscope stage (BX51WI, Olympus). Neurons that showed EGFP fluorescence were subjected to electrophysiological re- cording. The fluorescence microscope was equipped with an infrared camera (C2741-79, Hamamatsu Photonics, Hamamatsu, Japan) for infrared differential interference contrast imaging and a CCD camera (IKTU51CU, Olympus) for fluorescent imaging. Each image was displayed separately on a monitor (Gawin, EIZO, Tokyo, Japan) and was saved on a Power Macintosh G4 computer (Apple, Cupertino, CA) through a graphic converter (PIX-MPTV, Pixcela, Osaka, Japan). Recordings were performed with an Axopatch 200B amplifier (Molecular Devices, Union City, CA) using a borosilicate pipette (GC150-10, Harvard Apparatus, Holliston, MA) prepared by a micropipette puller (P-97, Sutter Instruments) filled with intracellular solution (4-10 M $\Omega$ ), consisting of the following (in mM): $145 \mathrm{KCl}, 1 \mathrm{MgCl}_{2}, 10$ HEPES, $1.1 \mathrm{EGTA}^{-\mathrm{Na}_{3}, 2}$ MgATP, $0.5 \mathrm{Na}_{2} \mathrm{GTP}$, pH 7.3 with $\mathrm{KOH}$. Osmolarity of the solution was checked by a vapor pressure osmometer (model 5520, Wescor, Logan, UT). The osmolarity of the internal and external solutions was $280-290$ and $320-330 \mathrm{mOsm} / \mathrm{L}$, respectively. The liquid junction potential of the patch pipette and perfused extracellular solution was estimated to be 3.9 $\mathrm{mV}$ and was applied to the data. Recording pipettes were under positive pressure while advanced toward individual cells in the slice. Tight seals on the order of $1.0-1.5 \mathrm{G} \Omega$ were made by negative pressure. The membrane patch was then ruptured by suction. The series resistance during recording was $10-25 \mathrm{M} \Omega$. The reference electrode was an $\mathrm{Ag}-\mathrm{AgCl}$ pellet immersed in bath solution. During recordings, cells were superfused with extracellular solution at a rate of $1.6 \mathrm{ml} / \mathrm{min}$ using a peristaltic pump (Dynamax, Rainin, Oakland, CA). Depolarization and hyperpolarizing current pulses were applied to cells at durations of $200 \mathrm{~ms}$ at $10 \mathrm{pA}$ steps at $2 \mathrm{~s}$ intervals from the resting membrane potential $(-60 \mathrm{mV})$ set by varying the intensity of a constantly injected current.

The output signal was low-pass filtered at $5 \mathrm{kHz}$ and digitized at 10 $\mathrm{kHz}$. Data were recorded on a computer through a Digidata $1322 \mathrm{~A}$ analog-to-digital converter using p-Clamp software version 8.2 (Molecular Devices). Traces were processed for presentation using Origin 6.1 (Origin Lab, Northampton, MA) and Canvas X (ACD Systems, Saanichton, British Columbia, Canada) software.

Drugs. AVP, oxytocin, and sulfated octapeptide form of cholecystokinin (CCK-8S) (Peptide Institute, Osaka, Japan) were dissolved in extracellular solution and applied by local application. Tetrodotoxin (TTX) (Wako, Osaka, Japan) was dissolved in extracellular solution at a concentration of $1 \mu \mathrm{M}$ and applied by bath application. AVP receptor-selective antagonists SR49059, SSR149415, and SR121463 were kind gifts from Dr. Serradeil-Le gal (Sanofi-Synthelabo Recherché, France). These antagonists were dissolved in DMSO. An oxytocin receptor antagonist, $\left(\mathrm{d}\left(\mathrm{CH}_{2}\right)_{5}{ }^{1}, \mathrm{Tyr}(\mathrm{Me})^{2}, \mathrm{Thr}^{4}, \mathrm{Orn}^{8}\right.$, des-Gly- $\left.\mathrm{NH}_{2}{ }^{9}\right)$-vasotocin (OVTA) (BACHEM, Bubendorf, Switzerland) was dissolved in distilled water. GDP- $\beta$ S (Sigma, St. Louis, MO) was dissolved in the pipette solution. These selective antagonists were dissolved in extracellular solution with the vehicle concentration $<0.1 \%$ and were applied by bath application.

Immunohistochemistry. V1aR ${ }^{+/+}$and $V 1 a R^{-/-}$mice were deeply anesthetized with diethyl ether and perfused sequentially with $20 \mathrm{ml}$ of chilled saline and $20 \mathrm{ml}$ of chilled $4 \%$ paraformaldehyde in $0.1 \mathrm{M}$ phosphate buffer. The brains were removed and immersed in the same fixative solution for $24 \mathrm{~h}$ at $4^{\circ} \mathrm{C}$, and then immersed in the $30 \%$ sucrose solution for at least $2 \mathrm{~d}$. The brains were quickly frozen in embedding solution (Sakura Finetechnical, Tokyo, Japan). For orexin and V1aR double staining, coronal sections of wild-type and V1aR knock-out mice brains were incubated with rabbit anti-VlaR antiserum (1/500, Millipore, Billerica, MA) for $48 \mathrm{~h}$ at $4^{\circ} \mathrm{C}$. These sections were incubated with Alexa 594labeled anti-rabbit IgG (1/800, Invitrogen, Carlsbad, CA) for $1 \mathrm{~h}$ at room temperature (RT). The sections were then incubated with guinea pig anti-orexin antiserum $(1 / 500)$ for $48 \mathrm{~h}$ at $4^{\circ} \mathrm{C}$ and incubated with Alexa 488-labeled goat anti-guinea pig $\operatorname{IgG}(1 / 800$, Invitrogen) for $1 \mathrm{~h}$ at RT. The sections were mounted and examined with a fluorescence microscope (AX-70, Olympus). To confirm the specificity of antibodies, incubations without primary antibody were conducted as a negative control in each experiment, and no signal was observed.

Intracerebroventricular administration. Male wild-type mice (20-25 g, transgene negative littermate of orexin/ataxin-3 mice) or orexin/ataxin-3 hemizygous mice (25-27 g, N10 backcrossed to C57Black/6J) were housed under controlled lighting (12 h light/dark cycle; light on 8:00 
A.M. to 8:00 P.M. $)$ and temperature $\left(22^{\circ} \mathrm{C}\right)$ conditions. Food and water were available ad libitum. Mice were anesthetized with pentobarbital (50 $\mathrm{mg} / \mathrm{kg}$, i.p.) and positioned in a stereotaxic frame (David Kopf Instruments, Tujunga, CA). A guide cannula was implanted into the third ventricle under sterile conditions. The mice were then housed separately for a recovery period of at least $7 \mathrm{~d}$. The position of the cannula was verified by central administration of human NPY $(0.3 \mathrm{nmol}$, Peptide Institute) to test for a positive response. Mice that ate at least $0.5 \mathrm{~g}$ of food over a $1 \mathrm{~h}$ period after injection were used for experiments. Three nanograms and $10 \mathrm{ng}$ of AVP were delivered in saline at a volume of $3 \mu \mathrm{l}$ over $60 \mathrm{~s}$, and the injector was left in position for an additional $60 \mathrm{~s}$ to ensure complete dispersal of the drug. Saline alone was injected in the vehicle control experiment. Intracerebroventricular injection was initiated at 8:30 A.M. and was completed by 9:00 A.M. The locomotor activity of individual mice for $5 \mathrm{~h}$ after intracerebroventricular injection was assessed with an infrared activity monitor (Supermex, Muromachi Kikai, Tokyo, Japan) in Plexiglas cages to which mice had been well habituated. The chambers were light controlled ( $12 \mathrm{~h}$ light-dark cycle; light on 8:00 A.M. to 8:00 P.M.) and sound attenuated. The infrared activity monitor is a sensor mounted above the cage to detect changes in heat across multiple zones of the cage through an array of Fresnel lenses. The sensor's output signals representing magnitude of the animal's movement are digitally converted, stored in the interface memory, and transferred to a computer.

Water deprivation. Male (8-9 weeks old) orexin/ataxin-3 mice, wildtype mice (transgene negative littermate mice), $V 1 a R^{-/-}$mice, and wildtype mice $\left(\mathrm{VlaR}^{+/+}\right.$mice, littermate mice of $\mathrm{VlaR^{-/- }}$ mice) were subjected to water deprivation for $36 \mathrm{~h}$. The locomotor activity under the water deprivation was assessed with an infrared activity monitor. The experiment was performed in Plexiglas cages to which mice had been well habituated for at least 1 week. The locomotor activity during water deprivation was compared with the basal locomotor activity with water available ad libitum during sequential recording for $3 \mathrm{~d}$ before the water deprivation stage. Water deprivation was started at the beginning of dark period (8:00 P.M.). Plasma osmolarity was measured before and after water deprivation. Blood (50 $\mu \mathrm{l})$ was sampled from the tail vein. Plasma $(10 \mu \mathrm{l})$ was then obtained by centrifugation $(4000 \mathrm{rpm}$ for $15 \mathrm{~min}$ at $15^{\circ} \mathrm{C}$ ). Plasma osmolarity was measured by using a vapor pressure osmometer (model 5520, Wescor).

Statistical analysis. Data were analyzed by unpaired $t$ test, paired $t$ test, one-way ANOVA, or two-way ANOVA. ANOVA was followed by post hoc analysis of significance by the Fisher's protected least significant difference test using the Stat View 5.0 software package for Macintosh (Abacus Concepts, Berkeley, CA). Probability $(p)$ values $<0.05$ were considered statistically significant.

\section{Results}

AVP and oxytocin activates orexin neurons

We previously reported that intracellular calcium is altered in orexin neurons by a number of peptides, including CCK-8S, neurotensin, AVP, and oxytocin using orexin/YC2.1 mice (Tsujino et al., 2005). Here we studied the mechanism of AVP- and oxytocininduced activation of orexin neurons in detail by slice patch clamp using orexin/EGFP mice. Under current-clamp mode, AVP or oxytocin application depolarized the membrane potential and increased firing frequency in a concentration-dependent manner (Fig. 1A,F). AVP or oxytocin induced depolarization in the presence of TTX, suggesting that AVP directly activates the orexin neurons (Fig. $1 B$ ). One micromolar AVP and $1 \mu \mathrm{M} \mathrm{oxy-}$ tocin significantly increased firing frequency to $604 \pm 175 \%(n=$ $5, p<0.001$, ANOVA $)$ and $378 \pm 108 \%(n=5, p<0.001$, ANOVA) of control values, respectively (Fig. $1 D, G)$. Membrane depolarization induced by $1 \mu \mathrm{M}$ AVP and $1 \mu \mathrm{M}$ oxytocin in the presence of TTX was $9.3 \pm 2.7 \mathrm{mV}(n=5, p<0.05$, ANOVA) and $11.9 \pm 3.0 \mathrm{mV}(n=5, p<0.05$, ANOVA), respectively (Fig. $1 E, H)$. AVP-induced depolarization was completely inhibited by a nonhydrolyzable GDP analog, GDP- $\beta$ S. AVP $(1 \mu \mathrm{M})$ application induced $0.06 \pm 0.4 \mathrm{mV}$ in the presence of GDP- $\beta \mathrm{S}$ (500

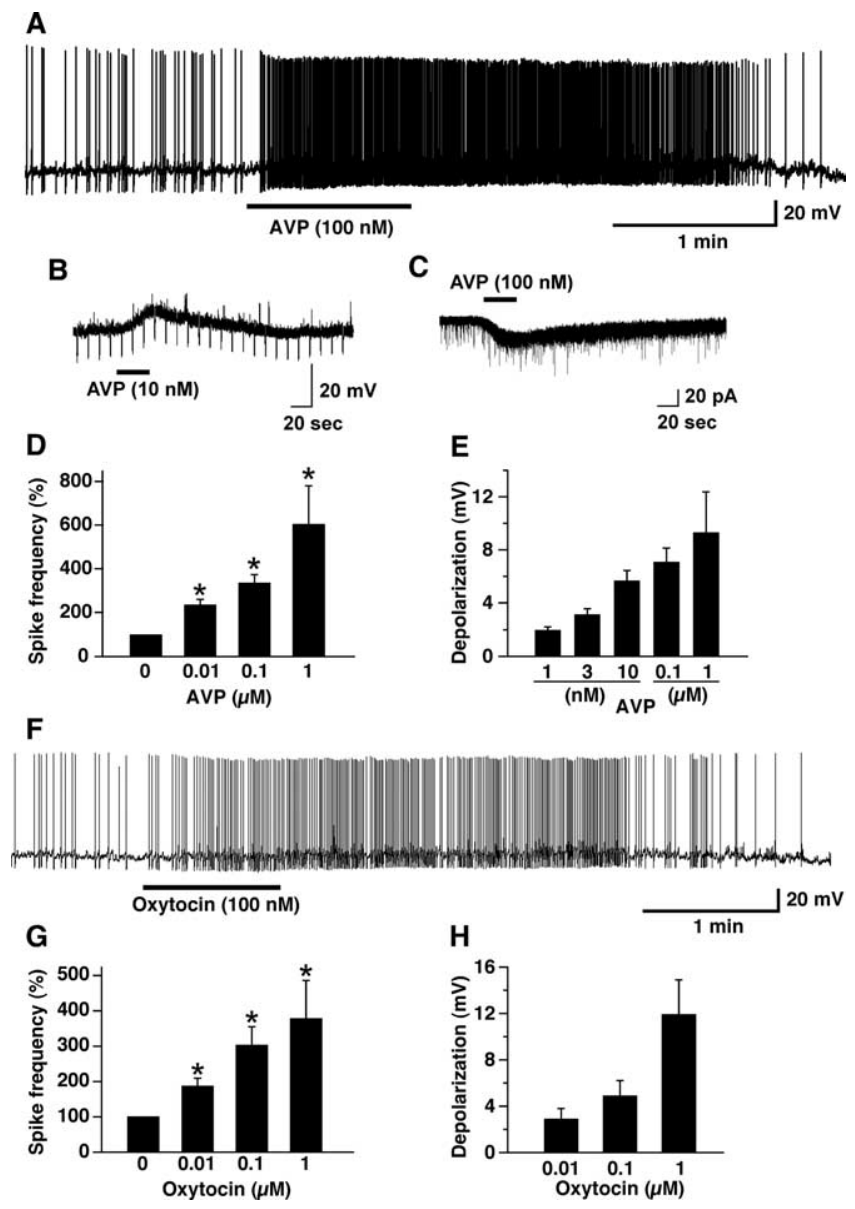

Figure 1. AVP and oxytocin excites orexin neurons. $\boldsymbol{A}$, Under current-clamp mode, AVP (100 nм) application induced depolarization and an increase in firing in the orexin neurons. $\boldsymbol{B}$, In the presence of TTX, AVP (10 nm) induced depolarization in the orexin neurons. $\boldsymbol{C}$, Under voltageclamp mode holding at $-60 \mathrm{mV}$, AVP application induced an inward current in the orexin neurons in the presence of TTX. $\boldsymbol{D}, \boldsymbol{E}$, AVP induced an increase in firing $(\boldsymbol{D})$ and depolarization $(\boldsymbol{E})$ in a concentration-dependent manner. $\boldsymbol{F}$, Under current-clamp mode, oxytocin application induced depolarization and an increase in firing in the orexin neurons. $\mathbf{G}, \boldsymbol{H}, 0$ xytocin induced an increase in firing $(\boldsymbol{G})$ and depolarization $(\boldsymbol{H})$ in a concentration-dependent manner. Peptides were applied by local application during the period represented by bars. Values are represented as mean \pm SEM. ${ }^{*} p<0.05$.

$\mu \mathrm{M})$ in the pipette solution ( $n=5, p=0.009$, unpaired $t$ test), suggesting that the depolarization is dependent on an activation of G-protein. Under voltage clamp, at a holding potential of $-60 \mathrm{mV}$, AVP and oxytocin induced inward current in orexin neurons (Fig. $1 C)$. One hundred nanomolar AVP and $1 \mu \mathrm{M}$ oxytocin induced $20.3 \pm 1.1 \mathrm{pA}(n=10)$ and $14.6 \pm 3.1 \mathrm{pA}(n=9)$, respectively. The AVP-induced inward current was not inhibited by a high concentration of strong calcium chelator, BAPTA $(10 \mathrm{~mm})$, in the pipette solution. The AVP (100 nM)-induced inward current was $22.4 \pm 2.8$ $\mathrm{pA}(n=5, p=0.008$, unpaired $t$ test $)$ in the presence of BAPTA, suggesting that the AVP-induced depolarization is independent from an increase in intracellular calcium. Almost all orexin neurons tested were depolarized by AVP (94\%, 231 of 245). A small number of orexin neurons showed no response or faint depolarization $(6 \%$, 14 of 245). In contrast, most EGFP-negative neurons ( $89 \% ; 17$ of 19 negative cells) showed no response to AVP (Table 1). Because $\sim 20 \%$ of orexin neurons show little detectable EGFP, the negative cells could contain a small proportion of orexin neurons (Yamanaka et al., 2003b). 
Table 1. Summary of AVP-induced response in the EGFP $(+)$ orexin neurons and $\operatorname{EGFP}(-)$ non-orexin neurons

\begin{tabular}{lllllr}
\hline & \multicolumn{2}{c}{ EGFP $(+)$ neurons } & & \multicolumn{2}{c}{ EGFP $(-)$ neurons } \\
\cline { 2 - 3 } \cline { 6 - 6 } & \multicolumn{1}{ll}{$n$} & $\%$ & & $n$ & $\%$ \\
\hline Activation & 231 & 94 & 2 & 11 \\
Inhibition & 0 & 0 & 0 & 0 \\
No effect & 14 & 6 & 17 & 89 \\
\hline
\end{tabular}

\section{V1aR is involved in AVP-induced activation of} orexin neurons

To identify which receptor is involved in AVP- and oxytocininduced activation of orexin neurons, AVP and oxytocin receptor-selective antagonists were applied. In the presence of TTX, orexin neurons were subjected to calcium imaging using the orexin/YC2.1 mice (Tsujino et al., 2005). Four subtypes of receptors are known for AVP and oxytocin in mammals: V1a, $\mathrm{V} 1 \mathrm{~b}, \mathrm{~V} 2$, and oxytocin receptor. AVP increased the YFP/CFP ratio, showing that intracellular calcium concentration $\left(\left[\mathrm{Ca}^{2+}\right]_{\mathrm{i}}\right)$ was increased. AVP-induced an increase in $\left[\mathrm{Ca}^{2+}\right]_{i}$ in a concentration-dependent manner (Fig. $2 A, B)\left(\mathrm{EC}_{50}=2.8 \pm 0.8\right.$ $\mathrm{nM}, n=10-19)$. Next, the receptor involved in this response was studied using receptor-selective antagonists. AVP (10 nM) was repeatedly applied on the brain slice three to four times. Repeated application induced almost the same amplitude of $\left[\mathrm{Ca}^{2+}\right]_{\mathrm{i}}$ increase compared with the first application (Fig. 2C). The first application was AVP alone, a control experiment. This value was used for normalization of the following experiments. The second application was vehicle control. AVP was applied in the presence of vehicle, which was used to dissolve the selective antagonists. The third and fourth AVP applications were performed in the presence of the selective antagonist. Vehicle had little effect on the AVP-induced increase in $\left[\mathrm{Ca}^{2+}\right]_{\mathrm{i}}$. The V1aR-selective antagonist, SR49059 (Serradeil-Le Gal et al., 1994, 2002a), significantly inhibited the AVP-induced increase in $\left[\mathrm{Ca}^{2+}\right]_{i}$ in a concentration-dependent manner (Fig. 2D,E). Ten nanomolar and $100 \mathrm{nM}$ SR 49059 inhibited to $52.9 \pm 3.9 \%(n=9, p<0.0001$, ANOVA $)$ and $9.3 \pm 3.4 \%(n=9, p<0.0001$, ANOVA $)$ of control value, respectively (Fig. $2 E$ ). In contrast, other receptor selective antagonists, including the $\mathrm{V} 1 \mathrm{~b}$ receptor-selective antagonist, SSR149415 (10 $\mu \mathrm{M}, n=23, p=0.436$, ANOVA) (Serradeil-Le Gal et al., 2002b), a V2 receptor-selective antagonist, SR121463 (10 $\mu \mathrm{M}, n=21, p=0.305$, ANOVA) (Serradeil-Le Gal, 2001), and oxytocin receptor-selective antagonist, OVTA $(1 \mu \mathrm{M}, n=9$, $p=0.757$, ANOVA) (Pequeux et al., 2002), did not inhibit the AVP-induced increase in $\left[\mathrm{Ca}^{2+}\right]_{\mathrm{i}}$ (Fig. 2 E). The inhibitory effect of SR49059 was further confirmed in electrophysiological experiments using orexin/EGFP mice. Under voltage-clamp mode, at a holding potential of $-60 \mathrm{mV}$, AVP (100 nM) induced $20.2 \pm 1.1$ pA $(n=9)$ of inward current. This AVP-induced inward current was significantly inhibited by SR49059 in a concentrationdependent manner (Fig. $2 F$ ). In the presence of 1 and $10 \mathrm{~nm}$ SR49509, the AVP-induced current was inhibited to $11.4 \pm 1.6$ $\mathrm{pA}(n=14, p<0.0001$, ANOVA $)$ and $1.8 \pm 1.0 \mathrm{pA}(n=7, p<$ 0.0001 , ANOVA), respectively. However, the V2 receptor antagonist, SR121463, did not inhibit AVP-induced current. AVP (100 $\mathrm{nM}$ ) induced $20.1 \pm 2.2 \mathrm{pA}$ of inward current in the presence of SR121463 (10 $\mu \mathrm{M})$ (Fig. $2 F, G)$, not significantly different from the current induced in the absence of the $\mathrm{V} 2$ receptor antagonist ( $n=6, p=0.97$, ANOVA). These results suggest that V1aR is involved in the AVP-induced activation of orexin neurons.
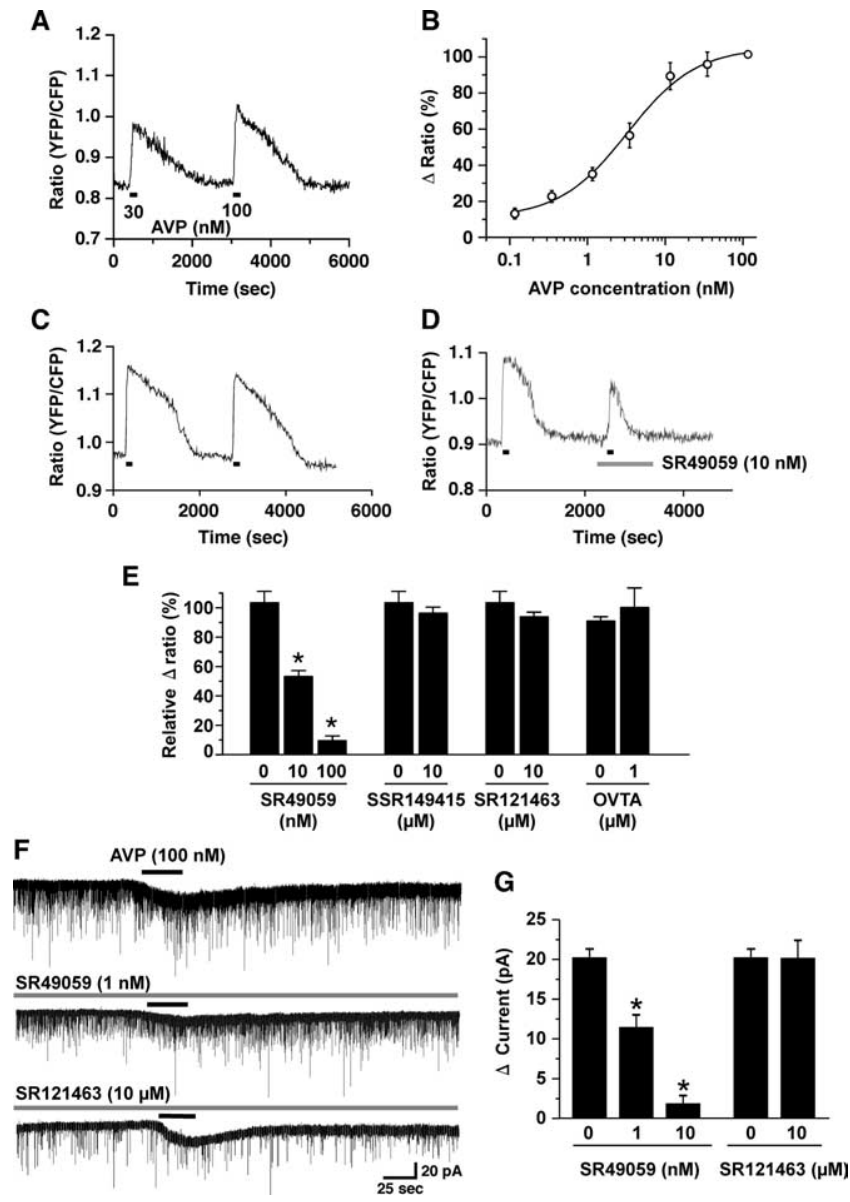

Figure 2. V1aR is involved in AVP-induced activation of orexin neurons. $\boldsymbol{A}, \boldsymbol{B}, \mathrm{AVP}$ increased $\left[\mathrm{Ca}^{2+}\right]_{\mathrm{i}}$ in the orexin neurons. AVP was applied by bath application during the period represented by bars. Orexin/YC2.1 transgenic mice brain slices were used for calcium imaging of orexin neurons. AVP increased $\left[\mathrm{Ca}^{2+}\right]_{\mathrm{i}}$ in the orexin neurons in a concentration-dependent manner. The $\mathrm{EC}_{50}$ value was $2.8 \pm 0.8 \mathrm{~nm}(n=10-19)$. The $\Delta$ ratio is normalized to a high concentration of AVP application ( $100 \mathrm{~nm})$. C, A repeated application of AVP ( $10 \mathrm{~nm})$ induced the same magnitude of response. AVP ( $10 \mathrm{~nm}$ ) was applied by bath application during the interval indicated by horizontal bars. D, E, SR49059, a V1a receptor-selective antagonist, inhibited AVP-induced increase in $\left[\mathrm{Ca}^{2+}\right]_{\mathrm{i}}$ in the orexin neurons. The bar graph summarizes the effect of AVP and oxytocin receptor-selective antagonists on AVP-induced response in the orexin neurons. In each experiment, AVP (10 nm) was repeatedly applied to the same brain slice three to four times. The first application was AVP alone. This value was used for normalization of the following experiments. The second application was vehicle control. AVP was applied in the presence of each vehicle. The third and fourth AVP application was performed in the presence of the selective antagonist. SSR149415, a V1b receptor-selective antagonist; SR121463, a V2 receptor-selective antagonist; OVTA, a oxytocin receptor-selective antagonist. The number under the bar graph shows the concentration of the selective antagonist. 0 refers to vehicle control. $\boldsymbol{F}$, AVP (100 nM)-induced inward current in the orexin neurons was inhibited by SR49059 in a concentration-dependent manner, but was not inhibited by SR121463 (10 $\mu \mathrm{m})$. AVP (100 nM) was applied by local application during the period represented by bars. Antagonists were applied by bath application for 2 min before experiments. $\mathbf{G}$, The bar graph summarizes the data in $\boldsymbol{F}$. Values are represented as mean \pm SEM. ${ }^{*} p<0.05$.

\section{V1aR immunoreactivity in orexin neurons}

To confirm the expression of $\mathrm{V} 1 \mathrm{aR}$ in orexin neurons, doublelabel immunofluorescence analyses were performed. The merged picture indicates that almost all orexin-immunoreactive neurons showed V1aR immunoreactivity (V1aR-ir) (Fig. 3, arrows). We also observed orexin-negative neurons in the hypothalamus that express V1aR (Fig. 3, arrowheads). To confirm specificity of the anti-V1aR antibody, $V 1 a R^{-/-}$mice brains were used. Although the number of orexin-immunoreactive neurons in the $V 1 a R^{-1-}$ 
mice was not distinguishable from that of wild-type mice (data not shown), neither orexin neurons nor other neurons in the hypothalamus showed V1aR-ir in the $V 1 a R^{-1-}$ mice. These results suggest that orexin neurons express V1aR.

\section{AVP and oxytocin failed to induce an inward current in orexin neurons in the $\mathrm{V}_{1 a R^{-/-}}$mice}

To further confirm the involvement of V1aR in AVP- and oxytocin-induced activation of orexin neurons, we generated $V 1 a R^{-/-}$; orexin/EGFP mice, in which the $V 1 a R$ gene is deficient throughout the body and orexin neurons specifically express EGFP. Basic membrane properties of orexin neurons in $V 1 a R^{-/-}$mice were not different from our previous reports (Yamanaka et al., 2003a; Muraki et al., 2004). Membrane capacitance, resting membrane potential, and membrane resistance of orexin neurons in $\mathrm{V}_{1 a R^{-/-}}$; orexin/EGFP mice were $30.8 \pm 3.0 \mathrm{pF}$ $(n=11),-55.9 \pm 0.9 \mathrm{mV}(n=11)$, and $494.6 \pm 58.6 \mathrm{M} \Omega$ $(n=9)$, respectively. Input resistance was calculated from the slope of the current-voltage relationship obtained by step current injection in current-clamp mode. CCK-8S was used as a positive control because we previously found that CCK-8S activates all orexin neurons by activation of nonselective cation channels via a $\mathrm{CCK}_{\mathrm{A}}$ receptor (Tsujino et al., 2005). Although the CCK-8S (30 $\mathrm{nM}$ )-induced inward current was not affected by a genotype of $V 1 a R$, the AVP (100 nM)-induced inward current was significantly reduced in $\mathrm{VlaR}^{+/-}$and was completely abolished in $V 1 a R^{-1-}$ mice (Fig. 4A,C). AVP (100 nM)-induced current in the orexin neurons in the $V 1 a R^{+/+}, V_{1 a R^{+/-}}$, and $V 1 a R^{-/-}$was $20.9 \pm 1.1 \mathrm{pA}(n=12), 14.7 \pm 1.2 \mathrm{pA}(n=6, p=0.005$, vs $\left.V 1 a R^{+/+}\right)$, and $0.0 \pm 0.0 \mathrm{pA}\left(n=8, p<0.0001\right.$, vs $\left.V 1 a R^{+/+}\right)$, respectively. On the other hand, CCK-8S-induced inward current in the orexin neurons in the $\mathrm{VlaR}^{+/+}, \mathrm{VlaR}^{+/-}$, and $V 1 a R^{-1-}$ was $15.9 \pm 1.1 \mathrm{pA}(n=12), 17.5 \pm 2.0 \mathrm{pA}(n=6, p=$ 0.39 , not significantly different, ANOVA), and $16.8 \pm 1.3 \mathrm{pA}$ ( $n=8, p=0.87$, not significantly different, ANOVA), respectively. Although higher concentrations of AVP [300 $\mathrm{nM}(n=3)$ and $1 \mu \mathrm{M}(n=4)$ ] were applied, these also failed to induce an inward current in the orexin neurons in the $V 1 a R^{-/-}$mice (data not shown). Not only AVP-induced current but also oxytocininduced inward current in the orexin neurons was completely abolished in $V 1 a R^{-/-}$mice. Even a high concentration of oxytocin (up to $3 \mu \mathrm{M}$ ) failed to induce an inward current in $V 1 a R^{-1-}$ mice $(n=6)$ (Fig. $4 B, C)$. These results strongly suggest that $\mathrm{V} 1 \mathrm{aR}$ is the primary receptor that is involved in both AVP- and oxytocin-induced activation of orexin neurons.

Activation of nonselective cation channels are involved in AVP- and oxytocin-induced activation of orexin neurons To examine the properties of the AVP-induced current in more detail, further electrophysiological experiments were performed. First, the contribution of $\mathrm{Na}^{+}$to this AVP-induced depolarization was studied. Experiments were done in which $\mathrm{NaCl}$ in the extracellular solution was replaced by an equimolar concentration of choline chloride in the presence of TTX $(1 \mu \mathrm{M})$. When choline was substituted for sodium, the AVP-induced inward current was strongly depressed. In $\mathrm{Na}^{+}$-free solution, the AVP $(100 \mathrm{nM})$-induced inward current was only $3.5 \pm 0.5 \mathrm{pA}(n=$ $5, p<0.0001$, ANOVA), suggesting that AVP-induced depolarization was primarily dependent on extracellular $\mathrm{Na}^{+}$. Next, to examine the contribution of calcium ions in this response, calcium was removed from the extracellular solution. Removal of extracellular calcium markedly potentiated the AVP-induced inward current (Fig. 5A, middle trace, $B$ ). In the presence or absence of calcium ions in the extracellular solution, the AVP (100 nM)-induced inward currents were $20.3 \pm$ $1.1 \mathrm{pA}$ or $179.5 \pm 5.9 \mathrm{pA}$, respectively $(n=7, p<0.0001$, ANOVA). The AVP-induced inward current increased $\sim 8.8$ fold in calcium-free solution, suggesting that the AVPinduced inward current was suppressed by extracellular calcium ions. The reversal potential of the AVP-induced current in the calcium-free extracellular solution (in mM: $140 \mathrm{NaCl}, 2 \mathrm{CsCl}$, $1 \mathrm{MgCl}_{2}, 1$ EGTA, 10 HEPES, and 10 glucose $)$ was near $0 \mathrm{mV}(6.9 \pm$ $1.2 \mathrm{mV}, n=6$ ) when measured using a CsCl pipette solution (in $\mathrm{mM}$ : $145 \mathrm{CsCl}, 1 \mathrm{MgCl}_{2}, 10$ HEPES, 1.1 EGTA, and $0.5 \mathrm{Na}_{2} \mathrm{GTP}$ ) (Fig. $5 C)$. The reversal potential of the oxytocin-induced current was also near $0 \mathrm{mV}(-3.1 \pm 8.9 \mathrm{mV}, n=4)$ (Fig. $5 D)$. These reversal potentials are consistent with activation of nonselective cation channels in AVP-induced depolarization of orexin neurons. Several recent reports suggest that the transient receptor potential (TRP) channel family plays an important role in the receptor-operated influx of cations (Spassova et al., 2004; Takai et al., 2004). In addition, the current through TRP channels is known to be suppressed by the presence of extracellular calcium ions (Lintschinger et al., 2000; Hill, 2001). To examine whether TRP channels are involved in the AVPinduced response, the effect of SKF96365, which is often used as a TRP channel blocker (Halaszovich et al., 2000), on the AVP-induced inward current was tested. SKF96365 significantly inhibited the AVP-induced inward current in a concentration-dependent manner. In the absence of extracellular calcium ions, the AVP-induced inward current was suppressed to $64.9 \pm 10.9 \mathrm{pA}(n=7, p<0.0001$, ANOVA $)$ and $33.4 \pm 5.3 \mathrm{pA}(n=9, p<0.0001$, ANOVA $)$ in the presence of 1 and $10 \mu \mathrm{M}$ SKF96365, respectively (Fig. 5A, bottom trace, $B)$. 


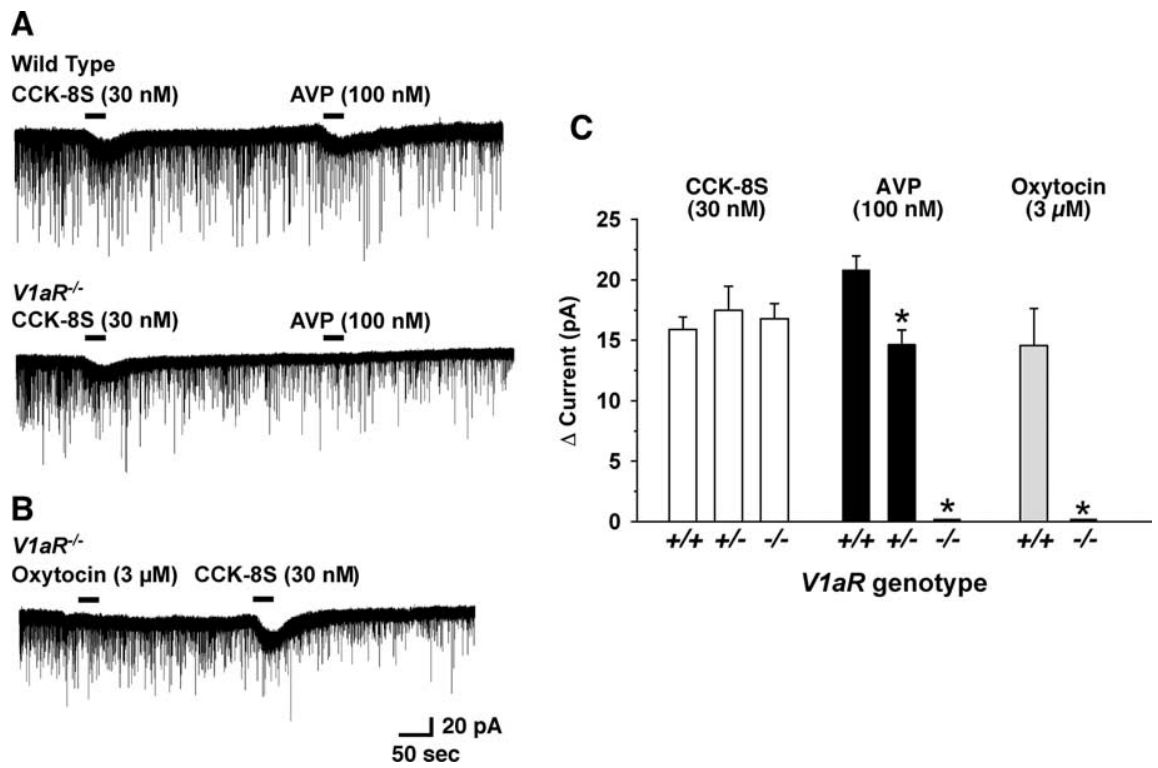

Figure 4. AVP and oxytocin failed to induce an inward current in the orexin neurons in the $V 1 a R^{-/-}$mice. $A$, Under voltageclamp mode at a holding potential of $-60 \mathrm{mV}, \mathrm{CCK}-8 \mathrm{~S}(30 \mathrm{~nm})$ and AVP $(100 \mathrm{~nm})$ were sequentially applied on the orexin neurons. The top trace is recorded from wild-type mice $\left(V 1 a R^{+/+}\right.$; orexin/EGFP mice). The bottom trace is recorded from V1aR ${ }^{-1-}$ $\left(V 1 a R^{-1-}\right.$; orexin/EGFP mice) mice. Although CCK-8S (30 nM)-induced inward current was observed in both V1aR ${ }^{+/+}$and $V 1 a R^{-/-}$mice, AVP (100 nm)-induced inward current was completely abolished in the orexin neurons in the V1aR ${ }^{-/-}$mice. $\boldsymbol{B}$, Oxytocin $(3 \mu \mathrm{M})$ failed to induce inward current in orexin neurons in the $V 1 a R^{-1-}$ mice as well. $C$, The bar graph summarizes the data in $\boldsymbol{A}$ and $\boldsymbol{B}$. Peptides were applied by local application during the period represented by bars. Values are represented as mean \pm SEM. ${ }^{*} p<0.05$.

Both calcium influx and calcium release are involved in AVPinduced activation of orexin neurons

To investigate the intracellular signal cascade of AVP-induced activation of orexin neurons, further electrophysiological or calcium imaging analysis was performed. V1aR is known to couple with a $\mathrm{G}_{\mathrm{q}} / 11$ subclass of $\mathrm{G}$-protein (Birnbaumer, 2000). The activated phospholipase $\mathrm{C} \beta$ (PLC $\beta$ ) promotes hydrolysis of phosphatidylinositol(4,5)-bisphosphate, thereby increasing the intracellular concentration of diacylglycerol and inositol $(1,4,5)$-triphosphate $\left(\mathrm{IP}_{3}\right)$. The latter stimulates calcium release from the endoplasmic reticulum (calcium store) via $\mathrm{IP}_{3}$ receptors. This rise in $\left[\mathrm{Ca}^{2+}\right]_{\mathrm{i}}$ initiates the cascade of calcium-mediated effects. We studied whether this cascade is involved in AVP-induced activation of orexin neurons. A selective PLC $\beta$ inhibitor, U73122, inhibited the AVPinduced inward current and an increase in $\left[\mathrm{Ca}^{2+}\right]_{i}$ in a concentration-dependent manner. In the presence of 1 and $5 \mu \mathrm{M}$ U73122, AVP (100 nM)-induced current $(20.2 \pm 1.1 \mathrm{pA}, n=9)$ was inhibited to $11.4 \pm 1.0 \mathrm{pA}(n=9, p<0.0001$, ANOVA $)$ and $5.4 \pm$ $0.5 \mathrm{pA}(n=7, p<0.0001$, ANOVA), respectively (Fig. $6 A, B)$. However, an inactive analog, U73343 $(10 \mu \mathrm{M})$, had little effect on both AVP-induced inward current $(18.7 \pm 1.2 \mathrm{pA}, n=6, p=0.32$, not significantly different, ANOVA) and the increase in $\left[\mathrm{Ca}^{2+}\right]_{\mathrm{i}}(83.1 \pm$ $6.6 \%$ of control values, $n=6, p=0.082$, not significantly different, ANOVA) (Fig. 6B, C). On the other hand, a selective phosphokinase $\mathrm{C}(\mathrm{PKC})$ inhibitor, calphostin $\mathrm{C}(100 \mathrm{nM})$, did not show any effect on AVP-induced increase in $\left[\mathrm{Ca}^{2+}\right]_{\mathrm{i}}$, suggesting that $\mathrm{PKC}$ is not involved in this response (Fig. $6 \mathrm{C}$ ).

To determine the source of the AVP-induced calcium mobilization, calcium imaging was performed in calcium-free extracellular solution. The AVP-induced increase in $\left[\mathrm{Ca}^{2+}\right]_{i}$ was significantly inhibited by $87.9 \pm 4.6 \%(n=9, p<0.0001$, ANOVA $)$ relative to control values by removal of calcium ion from the extracellular solution. Additionally, pretreatment of thapsigargin
$(1 \mu \mathrm{M})$ for $5 \mathrm{~min}$, which depletes intracellular calcium stores, also inhibited AVPinduced $\left[\mathrm{Ca}^{2+}\right]_{\mathrm{i}}$ to $55.2 \pm 5.9 \%(n=9$, $p<0.0001$, ANOVA) of control value. The AVP-induced increase in $\left[\mathrm{Ca}^{2+}\right]_{\mathrm{i}}$ was also inhibited to $63.7 \pm 9.2 \%(n=5, p<$ 0.0001, ANOVA) of control value by pretreatment of xestospongin $\mathrm{C}(3 \mu \mathrm{M})$, an $\mathrm{IP}_{3}$ receptor antagonist (Oka et al., 2002) for 5 min (Fig. 6D). These results suggest that an activation of PLC $\beta$ followed by an increase in $\left[\mathrm{Ca}^{2+}\right]_{\mathrm{i}}$ through both calcium influx from the extracellular space and calcium release from intracellular calcium stores are involved in the AVP-induced activation of orexin neurons via V1aR.

\section{Activation of orexin neurons through $\mathrm{V} 1 \mathrm{aR}$ is important in the regulation of locomotor activity and water} deprivation-induced behavioral responses

To investigate the physiological importance of AVP- or oxytocin-induced activation of orexin neurons in mice, AVP was injected into the third ventricle in wildtype and orexin/ataxin-3 transgenic mice. At this age (10 weeks), almost all orexin neurons are ablated in orexin/ataxin-3 mice (Hara et al., 2001). AVP was injected at the early light phase (8:30 A.M.), and locomotor activity was then monitored for $5 \mathrm{~h}$ after injection during the light period (9:00 A.M. to 2:00 P.M.). Vehicle alone (saline) was used as control experiment. Wild-type mice intracerebroventricularly injected with AVP (10 ng) showed a significant increase in locomotor activity $(n=6)$ (Fig. 7A). AVP induced an increased in locomotor activity in a dose-dependent manner (Fig. 7C). Total locomotor activity for $3 \mathrm{~h}$ after saline, 3 and $10 \mathrm{ng}$ AVP injection was $2548 \pm 605(n=6), 4546 \pm 783(n=6, p=0.037$, ANOVA $)$ and $5026 \pm 990(n=6, p=0.011$, ANOVA $)$ of control values, respectively. In contrast, AVP failed to increase locomotor activity in the orexin/ataxin-3 transgenic mice $(n=6)$ (Fig. $7 B, C)$. Total locomotor activity for $3 \mathrm{~h}$ after saline, 3 and $10 \mathrm{ng}$ AVP injection was $2553 \pm 327(n=6), 2216 \pm 460(n=6, p=0.88$, not significantly different, ANOVA $)$ and $2685 \pm 825(n=6, p=$ 0.72, not significantly different, ANOVA), respectively (Fig. 7C). These results suggest that the orexin neurons has an important role in the AVP-induced locomotor activity. This view is also supported by our finding that spontaneous locomotor activity of $V 1 a R^{-1-}$ mice was significantly lower than that of wild-type littermate mice (Fig. 7D). Spontaneous locomotor activity is represented by an average of sequential recordings for $3 \mathrm{~d}$. Total locomotor activity of $V 1 a R^{+/+}$mice and $V 1 a R^{-/-}$mice in the dark period (12 h, 8:00 P.M. to 8:00 A.M.) was $62,656 \pm 10,008(n=6)$ and 49,292 $\pm 3199(n=9, p=0.12$, not significantly different, unpaired $t$ test), respectively. Total locomotor activity of $V_{1 a R^{+/+}}$mice and $V 1 a R^{-/-}$mice in the light period $(12 \mathrm{~h}, 8: 00$ A.M. to 8:00 P.M.) was $15,462 \pm 2078(n=6)$ and $9647 \pm 1157$ ( $n=9, p=0.013$, unpaired $t$ test), respectively; and for the whole day $(24 \mathrm{~h})$, it was 78,119 $\pm 8445(n=6)$ and 58,940 $\pm 3415(n=$ $9, p=0.02$, unpaired $t$ test), respectively. To further investigate the physiological importance of AVP-induced activation of orexin neurons, wild-type mice and orexin/ataxin-3 mice were 
A
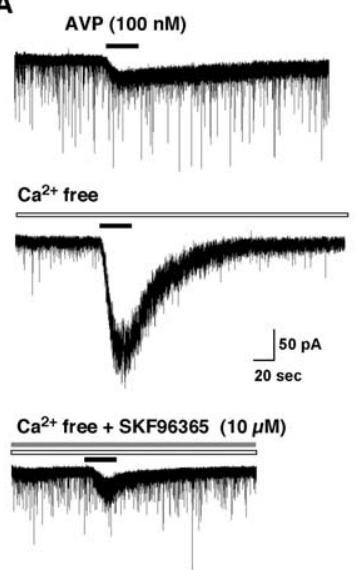

C

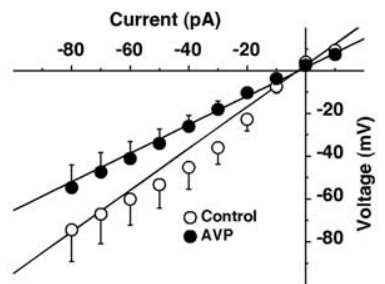

B

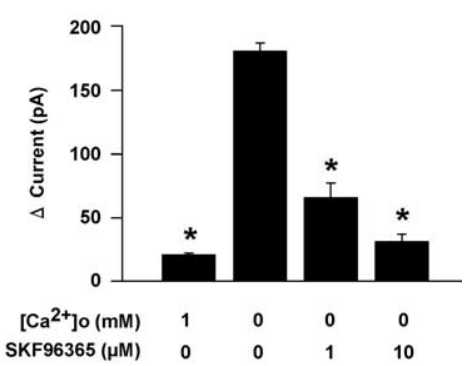

D

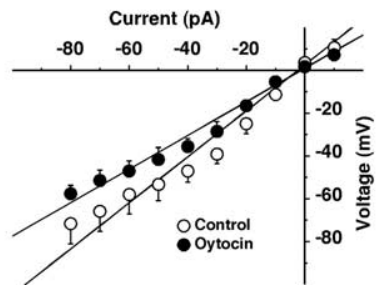

Figure 5. Activation of nonselective cation channel is involved in the AVP-induced activation of orexin neurons. A, AVP-induced inward current was dramatically increased in $\mathrm{Ca}^{2+}$ free solution (middle trace, $n=7$ ). This increased current was inhibited by pretreatment of SKF96365, a nonselective cation channel blocker, in a concentration-dependent manner. SKF96365 was applied by bath application for 2 min before experiment. AVP (100 nm) was applied by local application during the period represented by bars. $\boldsymbol{B}$, The bar graph summarizes the data in $\boldsymbol{A}$. C, D, Current-voltage relationship obtained by step current injection protocol using a CSCl pipette. $C$, The steady-state current at the end of the step current injection is plotted in a current-voltage relationship. I-V curve shows that the reversal potential of the AVP $(1 \mu \mathrm{M})$ and oxytocin (1 $\mu \mathrm{M})$-induced current was $6.9 \pm 1.2 \mathrm{mV}(n=6)$ and $-3.1 \pm 8.9 \mathrm{mV}(n=4)$, respectively. Under current-clamp mode, current was injected (-80 pA to $10 \mathrm{pA}$, in $10 \mathrm{pA}$ increment at a duration of $200 \mathrm{~ms}$ ). Open circles indicate control and filled circles indicate AVP (1 $\mu \mathrm{M})$ or oxytocin $(1 \mu \mathrm{M})$ application. Values are represented as mean \pm SEM. ${ }^{*} p<0.05$. $\left[\mathrm{Ca}^{2+}\right]_{0}$, Extracellular calcium concentration.

subjected to water deprivation. The locomotor activity during water deprivation was compared with spontaneous locomotor activity in ad libitum drinking (basal locomotor activity). Water deprivation increases the activity of vasopressin neurons in the supraoptic nucleus $(\mathrm{SON})$ and paraventricular nucleus $(\mathrm{PVN})$ and increases AVP concentration in the CSF (SzczepanskaSadowska et al., 1983; da Silveira et al., 2007). After 36 h of water deprivation, the plasma osmolarity was significantly increased in both wild-type mice and orexin/ataxin-3 mice. Plasma osmolarity of wild-type mice before and after water deprivation was $311.2 \pm$ 1.6 and $335.3 \pm 2.1 \mathrm{mOsm} / \mathrm{L}$, respectively, $n=6, p=0.0005$, paired $t$ test). Plasma osmolarity of orexin/ataxin-3 mice before and after water deprivation was $308.8 \pm 1.4$ and $330.3 \pm 2.4$ $\mathrm{mOsm} / \mathrm{L}$, respectively, $n=4, p=0.005$, paired $t$ test). Water deprivation significantly increased locomotor activity in the dark period in wild-type mice (Fig. 7 E, F). An increase in locomotor activity was found in the early dark period. The locomotor activity for $3 \mathrm{~h}(8: 00-11: 00$ P.M.) in the dark period was 11,198 \pm 2973 (basal) and 17,591 \pm 3342 (water deprivation, $n=6$, $p=0.0015$, paired $t$ test). The difference in locomotor activity in the early dark period could be caused by AVP release from magnocellular neurons, but hypothetically, could also relate to AVP release from parvocellular neurons of the suprachiasmatic nu-

A
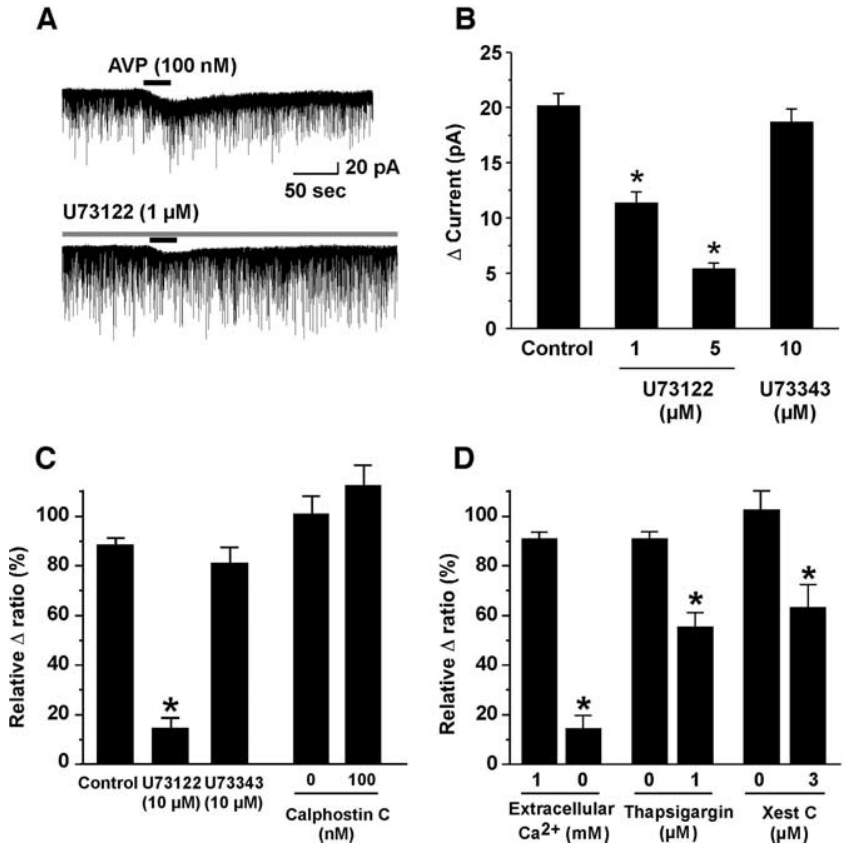

D

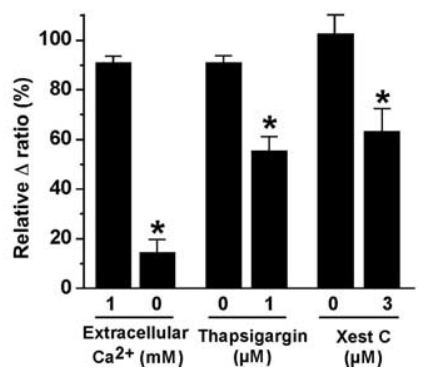

Figure 6. Both calcium influx through nonselective cation channel and calcium release from intracellular calcium stores via an $\mathbb{P}_{3}$ receptor are involved in AVP-induced activation of orexin neurons. $A, B, U 73122$, a selective PLC $\beta$ inhibitor, inhibited AVP-induced inward current in a concentration-dependent manner. However, U73343, an inactive analog of U73122, had little effect on AVP-induced inward current. $C$, AVP-induced increase in $\left[\mathrm{Ca}^{2+}\right]_{i}$ was also inhibited by U73122. On the other hand, calphostin C, a selective PKC inhibitor, had little effect on it. $\boldsymbol{D}$, AVP-induced increase in $\left[\mathrm{Ca}^{2+}\right]_{i}$ was almost abolished in the $\mathrm{Ca}^{2+}$ free extracellular solution. AVP-induced increase in $\left[\mathrm{Ca}^{2+}\right]_{i}$ was also inhibited by thapsigargin and xestospongin $C$, an inhibitor of ATP-dependent calcium uptake into the calcium store and a selective $\mathbb{I P}_{3}$ receptor antagonist, respectively. Values are represented as mean \pm SEM. ${ }^{*} p<0.05$. Xest C, Xestospongin C.

cleus (SCN), the circadian clock in the hypothalamus. In contrast, water deprivation did not induce an increase in locomotor activity in the orexin/ataxin-3 mice either in the light period or dark period. The locomotor activity for $3 \mathrm{~h}(8: 00-11: 00$ P.M.) in the dark period was $8351 \pm 2134$ (basal) and $8434 \pm 1159$ (water deprivation, $n=4, p=0.47$, not significantly different, paired $t$ test). V1aR ${ }^{-/-}$mice were also subjected to water deprivation to confirm an involvement of $\mathrm{V} 1 \mathrm{aR}$ in water deprivation-induced increase in locomotor activity (supplemental Fig. 1, available at www.jneurosci.org as supplemental material). Wild-type mice $\left(\mathrm{VlaR}^{+/+}\right.$mice, littermate of $\mathrm{VlaR}^{-/-}$mice) increased locomotor activity in the dark period during water deprivation. The locomotor activity for $3 \mathrm{~h}$ (8:00-11:00 P.M.) in the dark period was $25,955 \pm 5556$ (basal) and 36,154 \pm 7057 (water deprivation, $n=4, p=0.018$, paired $t$ test). However, $V 1 a R^{-/-}$mice failed to increase locomotor activity during water deprivation. The locomotor activity for $3 \mathrm{~h}$ (8:00-11:00 P.M.) in the dark period was $17,256 \pm 1979$ (basal) and 18,259 \pm 2673 (water deprivation, $n=$ $5, p=0.38$, not significantly different, paired $t$ test). Plasma osmolarity of wild-type mice before and after water deprivation was $311.3 \pm 2.2$ and $329.5 \pm 6.8 \mathrm{mOsm} / \mathrm{L}$, respectively, $n=4$, $p=0.0034$, paired $t$ test). Plasma osmolarity of $V 1 a R^{-1-}$ mice before and after water deprivation was $309.0 \pm 2.0$ and $335.8 \pm$ $4.2 \mathrm{mOsm} / \mathrm{L}$, respectively, $n=5, p=0.005$, paired $t$ test). These results suggest that AVP-induced activation of orexin neurons might be involved in increasing locomotor activity during water deprivation. 
A

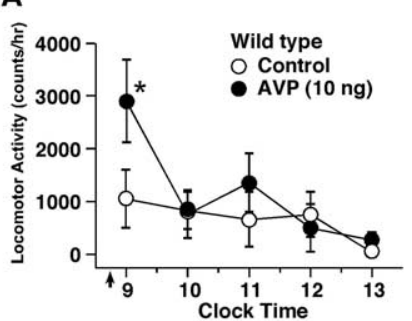

C

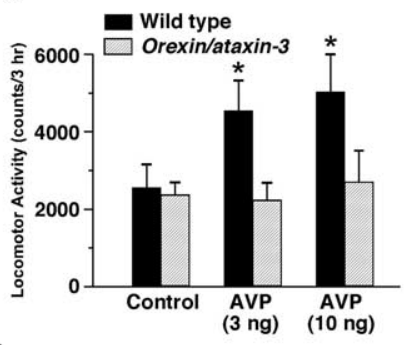

E
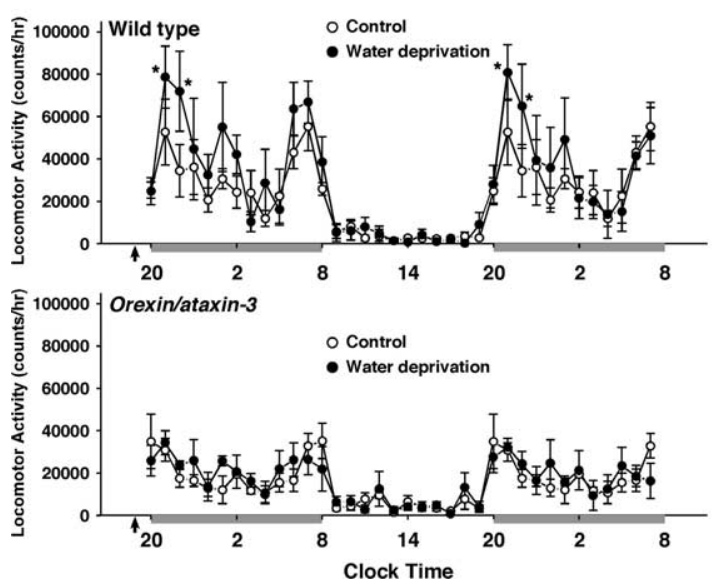

B

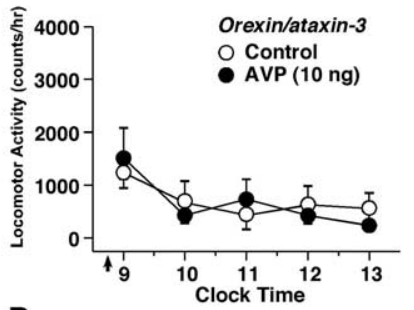

D

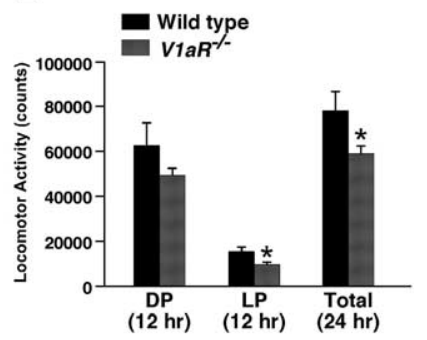

$\mathbf{F}$

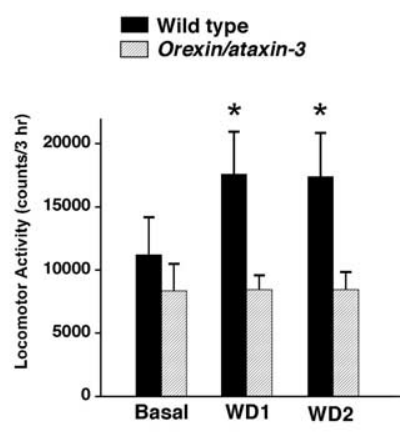

Figure 7. $\quad \boldsymbol{A}, \boldsymbol{B}$, Intracerebroventricular injection of AVP increased spontaneous locomotor activity in the light period in wildtype mice but not in orexin/ataxin-3 mice. AVP was injected into the third ventricle. The arrow shows the timing of intracerebroventricular injection. Intracerebroventricular injection was initiated at 8:30 A.M. and was completed by 9:00 A.M. Saline alone was injected in the vehicle control experiment. The locomotor activity of individual mice for $5 \mathrm{~h}$ after intracerebroventricular injection was assessed with an infrared activity monitor in Plexiglas cages to which mice had been well habituated. $\boldsymbol{C}$, The bar graph summarizes the data for $3 \mathrm{~h}$ after injection (9:00 A.M. to 12:00 P.M.) in $\boldsymbol{A}$ and $\boldsymbol{B}$. D, Basal locomotor activity of V1aR ${ }^{-/-}$ mice is lower than wild-type mice. Basal locomotor activity is the average of sequential recordings for $3 \mathrm{~d}$. $\boldsymbol{E}$, Water deprivation induced an increase in activity in the dark period in wild-type mice (top graph) but not in orexin/ataxin-3 mice (bottom graph). Water deprivation was started at the beginning of the dark period (arrows in the graph). The dark period is indicated by gray bars. $\boldsymbol{F}$, The bar graph summarizes the data in $\boldsymbol{E}$. The locomotor activity for $3 \mathrm{~h}$ (8:00-11:00 P.M.) was summarized. Values are represented as mean \pm SEM. ${ }^{*} p<0.05$. Orexin/ataxin-3, orexin/ataxin-3 transgenic mice. DP, Dark period (12 h: 8:00 P.M. to 8:00 A.M.). LP, Light period (12 h: 8:00 A.M. to 8:00 P.M.). Basal, Basal locomotor activity. WD1, Water deprivation in the first dark period. WD2, Water deprivation in the second dark period.

\section{Discussion}

In the present study, we show that orexin neurons are directly excited by AVP and oxytocin through the V1aR. Subsequently, a mechanism of activation of PLC $\beta$, nonselective cation channels and the $\mathrm{IP}_{3}$ receptor are involved in this response. Analysis of locomotor activity revealed that AVP-induced activation of orexin neurons is involved in the regulation of spontaneous locomotor activity and water deprivationinduced hyperlocomotor activity. These data suggest that the orexin system is involved not only in arousal related to energy homeostasis, but also arousal related to other homeostatic systems including water balance.

\section{The mechanism of}

AVP-induced depolarization

AVP and oxytocin are closely related peptides containing 9 aa. These peptides activate neurons in the lateral septum (Raggenbass et al., 1987), paraventricular nucleus (Inenaga and Yamashita, 1986), and subfornical organ (Anthes et al., 1997). In the present report, AVP activated almost all orexin neurons (231 of 245). In contrast, the majority of cells not expressing EGFP did not respond to AVP, underlining the selectivity of the response to the orexin neuron system. A few neurons that did not express EGFP did respond to vasopressin; these may be the orexin-negative cells that express V1aR immunoreactivity. It is also possible that these neurons are melanin-concentrating hormone neurons that are also located in the lateral hypothalamic area and are believed to be involved in feeding behavior and energy homeostasis.

The AVP-induced depolarization or inward current is not affected by TTX, suggesting a postsynaptic effect (a direct effect). Multiple lines of evidence suggest that VlaR is involved in AVP- and oxytocin-induced activation of orexin neurons. AVP-induced activation of the orexin neurons was inhibited by a selective VlaR antagonist in a concentrationdependent manner, but not by the other receptor-selective antagonists (V1b, V2, and oxytocin receptor antagonists). Additionally, VlaR immunoreactivity was observed in orexin neurons. These results are strongly supported by the results using $V 1 a R^{-1-}$ mice. Although the basic membrane characteristics of orexin neurons in $V 1 a R^{-/-}$mice were not distinguishable from those of the wild-type animal, the AVP-induced response in orexin neurons was significantly decreased in $V 1 a R^{+/-}$ mice and was completely abolished in the $V 1 a R^{-/-}$mice. Even a high concentration of oxytocin $(3 \mu \mathrm{M})$ failed to induce an inward current in the orexin neurons in the $V 1 a R^{-1-}$ mice. This result strongly suggests that not only AVP but also oxytocininduced inward current is mediated via $\mathrm{VlaR}$ in the orexin neurons.

Here we found that AVP activated nonselective cation channels in orexin neurons, similar to the channel activated by CCK-8S (Tsujino et al., 2005). The inward current induced by AVP was strongly potentiated by the removal of extracellular calcium ions and was inhibited by SKF96365. These characteristics are similar to those of nonselective cation channels activated by CCK- $8 \mathrm{~S}$ in orexin neurons, suggesting that the same nonselective cation channels (probably TRP channels) might be involved in the AVP-induced response. However, there is a difference in the source of calcium mobilization between the AVPinduced and the CCK-8S-induced responses. The CCK-8Sinduced increase in $\left[\mathrm{Ca}^{2+}\right]_{\mathrm{i}}$ was not inhibited by thapsigargin 
(Tsujino et al., 2005). In contrast, the AVP-induced response was sensitive to both thapsigargin and xestospongin C. The AVPinduced increase in $\left[\mathrm{Ca}^{2+}\right]_{\mathrm{i}}$ was inhibited $\sim 50 \%$ of control value by these compounds. Additionally, U73122 significantly inhibited both AVP-induced inward current and the increase in $\left[\mathrm{Ca}^{2+}\right]_{\mathrm{i}}$. An involvement of PLC $\beta$ downstream of V1aR is also found in cultured cortical neurons (Son and Brinton, 2001). These results suggest that the calcium influx from the extracellular solution is the main source of the CCK-8S-induced response, whereas both calcium influx and calcium release from intracellular calcium stores are involved in the AVP-induced response.

\section{Physiological significance of AVP and oxytocin-mediated activation of orexin neurons}

Where might an AVP or oxytocin input to orexin neurons arise? AVP or oxytocin neurons are located in the SON, SCN (Sofroniew and Weindl, 1980), PVN, bed nucleus of stria terminalis (Armstrong et al., 1980; Sawchenko and Swanson, 1982; Rosen et al., 2006), or central amygdala (Dubois-Dauphin et al., 1989).

Osmotic stimuli activate SON neurons (Mason, 1980) and increase c-fos protein expression in AVP and oxytocin neurons in the SON and PVN (Pirnik et al., 2004; Arnhold et al., 2007). These increases in the release of AVP and oxytocin from SON and PVN might be involved in an activation of orexin neurons under dehydration. Alternatively, an increase in AVP or oxytocin concentration in the CSF might activate orexin neurons via a humoral mechanism. On the other hand, recent analyses of afferents to orexin neurons revealed that orexin neurons receive innervations from neurons in the amygdala (Sakurai et al., 2005; Yoshida et al., 2006). The amygdala is implicated in the generation of emotions such as fear and anxiety. This pathway is believed to play an important role in fear- and anxiety-induced arousal. VlaR antagonist has been shown to block aggressive behavior (Ferris et al., 2006). In addition, $V 1 a R^{-/-}$mice display an impairment of social interaction (Bielsky et al., 2005) and reduced anxiety-related behavior (Egashira et al., 2007), suggesting that AVP and oxytocin may be involved in excitatory inputs from the amygdala to orexin neurons.

What is the physiological role of AVP- and oxytocin-induced activation of orexin neurons? Intracerebroventricular injection of AVP induced an increase in locomotor activity in wild-type mice during the light period. However, AVP failed to induce hyperlocomotor activity in orexin/ataxin-3 mice. This suggests that AVP-induced hyperlocomotor activity is mediated via activation of orexin neurons. Intracerebroventricular injection of orexin increased not only feeding behavior and arousal (Espana et al., 2002) but also spontaneous locomotor activity (Nakamura et al., 2000; Matsuzaki et al., 2002), in good agreement with our results. Intracerebroventricular injection of AVP or oxytocin increased the time spent in the waking state in rats (Arnauld et al., 1989) and increased the heart rate (Diamant and De Wied, 1993). These effects might be mediated via activation of orexin neurons through V1aR because activation of orexin neurons resulted in an increase in arousal (Nishino, 2007) and sympathetic tone (Shirasaka et al., 2003). Under dehydration, AVP concentration increases in the blood and CSF (Szczepanska-Sadowska et al., 1983). It acts in concert with the sympathetic nervous system and renin-angiotensin system to maintain circulation. In peripheral tissues, AVP directly induces vasoconstriction and antidiuresis for volume control. In the CNS, AVP modulates the baroreflex and increases sympathetic outflow. In parallel with these effects, AVP increases locomotor activity through the activation of orexin neurons. Involvement of the V1aR-mediated activation of orexin neurons in the regulation of spontaneous locomotor activity is also supported by the finding that spontaneous locomotor activity of $V 1 a R^{-/-}$mice was significantly lower than that of wild-type mice.

Although it is well known that dehydration induces hyperlocomotor activity in animals (Finger and Reid, 1952; Hall, 1955), the mechanism for this, as yet, has not been elucidated in detail. Water deprivation induced hyperlocomotor activity in wild-type mice but not in orexin/ataxin-3 mice during the early dark period. Additionally, $V 1 a R^{-/-}$mice failed to increase locomotor activity during water deprivation. These results suggest that activation of orexin neurons through $\mathrm{VlaR}$ is involved in the water deprivation-induced hyperlocomotor activity in mice. We previously reported that intracerebroventricular injection of orexin A increases water intake, and water deprivation for $24 \mathrm{~h}$ upregulates orexin mRNA in rats (Kunii et al., 1999). These findings suggest that orexin neurons are involved in drinking behavior as well as feeding behavior. The increase in locomotor activity appears to be a response to dehydration aimed at maintaining fluid homeostasis. Such action might increase the chance of finding new sources of water. A similar type of response was observed during food deprivation. Food deprivation increases the time spent awake and also induces hyperlocomotor activity in mice through activation of orexin neurons (Yamanaka et al., 2003b). Activation of orexin neurons during an emergency situation such as dehydration or hunger might increase the likelihood of survival for animals in nature.

Mechanistically, AVP- and oxytocin-induced activation of orexin neurons is mediated through V1aR. Activation of PLC $\beta$ is involved in the intracellular signaling cascade downstream of $\mathrm{V} 1 \mathrm{aR}$ and leads to an increase in intracellular calcium ion concentration via both calcium influx through the nonselective cation channels and calcium release from calcium stores through the $\mathrm{IP}_{3}$ receptor. The activation of orexin neurons by AVP or oxytocin has an important role in the regulation of spontaneous locomotor activity in mice. This system appears to play a key role in water deprivation-induced hyperlocomotor activity, a response to ensure survival for dehydration. This response increases the chance of locating water in nature. Our finding that both AVP and oxytocin directly excited the orexin arousal system also suggests that the orexin system may be involved in arousal related to a number of behaviors including responses to stress, maternal behavior, and aggression.

\section{References}

Anthes N, Schmid HA, Hashimoto M, Riediger T, Simon E (1997) Heterogeneous actions of vasopressin on ANG II-sensitive neurons in the subfornical organ of rats. Am J Physiol 273:R2105-2111.

Armstrong WE, Warach S, Hatton GI, McNeill TH (1980) Subnuclei in the rat hypothalamic paraventricular nucleus: a cytoarchitectural, horseradish peroxidase and immunocytochemical analysis. Neuroscience 5:1931-1958.

Arnauld E, Bibene V, Meynard J, Rodriguez F, Vincent JD (1989) Effects of chronic icv infusion of vasopressin on sleep-waking cycle of rats. Am J Physiol 256:R674-R684.

Arnhold MM, Wotus C, Engeland WC (2007) Differential regulation of parvocellular neuronal activity in the paraventricular nucleus of the hypothalamus following single vs. repeated episodes of water restrictioninduced drinking. Exp Neurol 206:126-136.

Bielsky IF, Hu SB, Ren X, Terwilliger EF, Young LJ (2005) The V1a vasopressin receptor is necessary and sufficient for normal social recognition: a gene replacement study. Neuron 47:503-513.

Birnbaumer M (2000) Vasopressin receptors. Trends Endocrinol Metab 11:406-410.

Brown RE, Sergeeva O, Eriksson KS, Haas HL (2001) Orexin A excites sero- 
tonergic neurons in the dorsal raphe nucleus of the rat. Neuropharmacology 40:457-459.

da Silveira LT, Junta CM, Monesi N, de Oliveira-Pelegrin GR, Passos GA, Rocha MJ (2007) Time course of c-fos, vasopressin and oxytocin mRNA expression in the hypothalamus following long-term dehydration. Cell Mol Neurobiol 27:575-584.

de Lecea L, Kilduff TS, Peyron C, Gao X, Foye PE, Danielson PE, Fukuhara C, Battenberg EL, Gautvik VT, Bartlett II FS, Frankel WN, van den Pol AN, Bloom FE, Gautvik KM, Sutcliffe JG (1998) The hypocretins: hypothalamus-specific peptides with neuroexcitatory activity. Proc Natl Acad Sci USA 95:322-327.

Diamant M, De Wied D (1993) Differential effects of centrally injected AVP on heart rate, core temperature, and behavior in rats. Am J Physiol 264:R51-R61.

Dubois-Dauphin M, Tribollet E, Dreifuss JJ (1989) Distribution of neurohypophysial peptides in the guinea pig brain. I. An immunocytochemical study of the vasopressin-related glycopeptide. Brain Res 496:45-65.

Egashira N, Tanoue A, Higashihara F, Mishima K, Fukue Y, Takano Y, Tsujimoto G, Iwasaki K, Fujiwara M (2004) V1a receptor knockout mice exhibit impairment of spatial memory in an eight-arm radial maze. Neurosci Lett 356:195-198.

Egashira N, Tanoue A, Matsuda T, Koushi E, Harada S, Takano Y, Tsujimoto G, Mishima K, Iwasaki K, Fujiwara M (2007) Impaired social interaction and reduced anxiety-related behavior in vasopressin V1a receptor knockout mice. Behav Brain Res 178:123-127.

Eggermann E, Serafin M, Bayer L, Machard D, Saint-Mleux B, Jones BE, Muhlethaler M (2001) Orexins/hypocretins excite basal forebrain cholinergic neurones. Neuroscience 108:177-181.

Espana RA, Plahn S, Berridge CW (2002) Circadian-dependent and circadian-independent behavioral actions of hypocretin/orexin. Brain Res 943:224-236.

Ferris CF, Lu SF, Messenger T, Guillon CD, Heindel N, Miller M, Koppel G, Robert Bruns F, Simon NG (2006) Orally active vasopressin V1a receptor antagonist, SRX251, selectively blocks aggressive behavior. Pharmacol Biochem Behav 83:169-174.

Finger FW, Reid LS (1952) The effect of water deprivation and subsequent satiation upon general activity in the rat. J Comp Physiol Psychol 45:368-372.

Fu LY, Acuna-Goycolea C, van den Pol AN (2004) Neuropeptide Y inhibits hypocretin/orexin neurons by multiple presynaptic and postsynaptic mechanisms: tonic depression of the hypothalamic arousal system. J Neurosci 24:8741-8751.

Halaszovich CR, Zitt C, Jungling E, Luckhoff A (2000) Inhibition of TRP3 channels by lanthanides. Block from the cytosolic side of the plasma membrane. J Biol Chem 275:37423-37428.

Hall JF (1955) Activity as a function of a restricted drinking schedule. J Comp Physiol Psychol 48:265-266.

Hara J, Beuckmann CT, Nambu T, Willie JT, Chemelli RM, Sinton CM, Sugiyama F, Yagami K, Goto K, Yanagisawa M, Sakurai T (2001) Genetic ablation of orexin neurons in mice results in narcolepsy, hypophagia, and obesity. Neuron 30:345-354.

Hill B (2001) Ion channels of excitable membranes. Sunderland, MA: Sinauer.

Hiroyama M, Aoyagi T, Fujiwara Y, Birumachi J, Shigematsu Y, Kiwaki K, Tasaki R, Endo F, Tanoue A (2007) Hypermetabolism of fat in Vla vasopressin receptor knockout mice. Mol Endocrinol 21:247-258.

Horvath TL, Peyron C, Diano S, Ivanov A, Aston-Jones G, Kilduff TS, van Den Pol AN (1999) Hypocretin (orexin) activation and synaptic innervation of the locus coeruleus noradrenergic system. J Comp Neurol 415:145-159.

Inenaga K, Yamashita H (1986) Excitation of neurones in the rat paraventricular nucleus in vitro by vasopressin and oxytocin. J Physiol (Lond) 370:165-180.

Kunii K, Yamanaka A, Nambu T, Matsuzaki I, Goto K, Sakurai T (1999) Orexins/hypocretins regulate drinking behaviour. Brain Res 842:256-261.

Lintschinger B, Balzer-Geldsetzer M, Baskaran T, Graier WF, Romanin C, Zhu MX, Groschner K (2000) Coassembly of Trp1 and Trp3 proteins generates diacylglycerol- and $\mathrm{Ca}^{2+}$-sensitive cation channels. J Biol Chem 275:27799-27805.

Liu ZW, Gao XB (2007) Adenosine inhibits activity of hypocretin/orexin neurons by the $\mathrm{A} 1$ receptor in the lateral hypothalamus: a possible sleeppromoting effect. J Neurophysiol 97:837-848.

Mason WT (1980) Supraoptic neurones of rat hypothalamus are osmosensitive. Nature 287:154-157.

Matsuzaki I, Sakurai T, Kunii K, Nakamura T, Yanagisawa M, Goto K (2002) Involvement of the serotonergic system in orexin-induced behavioral alterations in rats. Regul Pept 104:119-123.

Muraki Y, Yamanaka A, Tsujino N, Kilduff TS, Goto K, Sakurai T (2004) Serotonergic regulation of the orexin/hypocretin neurons through the 5-HT1A receptor. J Neurosci 24:7159-7166.

Nakamura T, Uramura K, Nambu T, Yada T, Goto K, Yanagisawa M, Sakurai $\mathrm{T}$ (2000) Orexin-induced hyperlocomotion and stereotypy are mediated by the dopaminergic system. Brain Res 873:181-187.

Nishino S (2007) The hypothalamic peptidergic system, hypocretin/orexin and vigilance control. Neuropeptides 41:117-133.

Oka T, Sato K, Hori M, Ozaki H, Karaki H (2002) Xestospongin C, a novel blocker of IP3 receptor, attenuates the increase in cytosolic calcium level and degranulation that is induced by antigen in RBL-2H3 mast cells. $\mathrm{Br} \mathrm{J}$ Pharmacol 135:1959-1966.

Pequeux C, Breton C, Hendrick JC, Hagelstein MT, Martens H, Winkler R, Geenen V, Legros JJ (2002) Oxytocin synthesis and oxytocin receptor expression by cell lines of human small cell carcinoma of the lung stimulate tumor growth through autocrine/paracrine signaling. Cancer Res 62:4623-4629.

Pirnik Z, Mravec B, Kiss A (2004) Fos protein expression in mouse hypothalamic paraventricular (PVN) and supraoptic (SON) nuclei upon osmotic stimulus: colocalization with vasopressin, oxytocin, and tyrosine hydroxylase. Neurochem Int 45:597-607.

Raggenbass M, Tribollet E, Dreifuss JJ (1987) Electrophysiological and autoradiographical evidence of $\mathrm{V} 1$ vasopressin receptors in the lateral septum of the rat brain. Proc Natl Acad Sci USA 84:7778-7782.

Rosen GJ, De Vries GJ, Villalba C, Weldele ML, Place NJ, Coscia EM, Glickman SE, Forger NG (2006) Distribution of vasopressin in the forebrain of spotted hyenas. J Comp Neurol 498:80-92.

Sakurai T, Nagata R, Yamanaka A, Kawamura H, Tsujino N, Muraki Y, Kageyama H, Kunita S, Takahashi S, Goto K, Koyama Y, Shioda S, Yanagisawa M (2005) Input of orexin/hypocretin neurons revealed by a genetically encoded tracer in mice. Neuron 46:297-308.

Sakurai T, Amemiya A, Ishii M, Matsuzaki I, Chemelli RM, Tanaka H, Williams SC, Richardson JA, Kozlowski GP, Wilson S, Arch JR, Buckingham RE, Haynes AC, Carr SA, Annan RS, McNulty DE, Liu WS, Terrett JA, Elshourbagy NA, Bergsma DJ, et al. (1998) Orexins and orexin receptors: a family of hypothalamic neuropeptides and $G$ protein-coupled receptors that regulate feeding behavior. Cell 92:573-585.

Sawchenko PE, Swanson LW (1982) Immunohistochemical identification of neurons in the paraventricular nucleus of the hypothalamus that project to the medulla or to the spinal cord in the rat. J Comp Neurol 205:260-272.

Serradeil-Le Gal C (2001) An overview of SR121463, a selective nonpeptide vasopressin V(2) receptor antagonist. Cardiovasc Drug Rev 19:201-214.

Serradeil-Le Gal C, Bourrie B, Raufaste D, Carayon P, Garcia C, Maffrand JP, Le Fur G, Casellas P (1994) Effect of a new, potent, non-peptide V1a vasopressin antagonist, SR 49059, on the binding and the mitogenic activity of vasopressin on Swiss 3T3 cells. Biochem Pharmacol 47:633-641.

Serradeil-Le Gal C, Wagnon J, Valette G, Garcia G, Pascal M, Maffrand JP, Le Fur G (2002a) Nonpeptide vasopressin receptor antagonists: development of selective and orally active V1a, V2 and V1b receptor ligands. Prog Brain Res 139:197-210.

Serradeil-Le Gal C, Wagnon J, Simiand J, Griebel G, Lacour C, Guillon G, Barberis C, Brossard G, Soubrie P, Nisato D, Pascal M, Pruss R, Scatton B, Maffrand JP, Le Fur G (2002b) Characterization of (2S,4R)-1-[5chloro-1-[(2,4-dimethoxyphenyl)sulfonyl]-3-(2-methoxy-phenyl)-2oxo-2,3-dihydro-1H-indol-3-yl]-4-hydroxy-N,N-dimethyl-2-pyrrolidine carboxamide (SSR149415), a selective and orally active vasopressin V1b receptor antagonist. J Pharmacol Exp Ther 300:1122-1130.

Shirasaka T, Takasaki M, Kannan H (2003) Cardiovascular effects of leptin and orexins. Am J Physiol Regul Integr Comp Physiol 284:R639-651.

Sofroniew MV, Weindl A (1980) Identification of parvocellular vasopressin 
and neurophysin neurons in the suprachiasmatic nucleus of a variety of mammals including primates. J Comp Neurol 193:659-675.

Son MC, Brinton RD (2001) Regulation and mechanism of L-type calcium channel activation via V1a vasopressin receptor activation in cultured cortical neurons. Neurobiol Learn Mem 76:388-402.

Spassova MA, Soboloff J, He LP, Hewavitharana T, Xu W, Venkatachalam K, van Rossum DB, Patterson RL, Gill DL (2004) Calcium entry mediated by SOCs and TRP channels: variations and enigma. Biochim Biophys Acta 1742:9-20.

Szczepanska-Sadowska E, Gray D, Simon-Oppermann C (1983) Vasopressin in blood and third ventricle CSF during dehydration, thirst, and hemorrhage. Am J Physiol 245:R549-555.

Takai Y, Sugawara R, Ohinata H, Takai A (2004) Two types of non-selective cation channel opened by muscarinic stimulation with carbachol in bovine ciliary muscle cells. J Physiol (Lond) 559:899-922.

Tsujino N, Yamanaka A, Ichiki K, Muraki Y, Kilduff TS, Yagami K, Takahashi S, Goto K, Sakurai T (2005) Cholecystokinin activates orexin/hypocretin neurons through the cholecystokinin A receptor. J Neurosci 25:7459-7469.
Winslow JT, Insel TR (2002) The social deficits of the oxytocin knockout mouse. Neuropeptides 36:221-229.

Yamanaka A, Tsujino N, Funahashi H, Honda K, Guan JL, Wang QP, Tominaga M, Goto K, Shioda S, Sakurai T (2002) Orexins activate histaminergic neurons via the orexin 2 receptor. Biochem Biophys Res Commun 290:1237-1245.

Yamanaka A, Muraki Y, Tsujino N, Goto K, Sakurai T (2003a) Regulation of orexin neurons by the monoaminergic and cholinergic systems. Biochem Biophys Res Commun 303:120-129.

Yamanaka A, Beuckmann CT, Willie JT, Hara J, Tsujino N, Mieda M, Tominaga M, Yagami K, Sugiyama F, Goto K, Yanagisawa M, Sakurai T (2003b) Hypothalamic orexin neurons regulate arousal according to energy balance in mice. Neuron 38:701-713.

Yamanaka A, Muraki Y, Ichiki K, Tsujino N, Kilduff TS, Goto K, Sakurai T (2006) Orexin neurons are directly and indirectly regulated by catecholamines in a complex manner. J Neurophysiol 96:284-298.

Yoshida K, McCormack S, Espana RA, Crocker A, Scammell TE (2006) Afferents to the orexin neurons of the rat brain. J Comp Neurol 494:845861. 